\title{
THE EVOLUTION OF CHINA'S PRIVATE EDUCATION POLICY: HISTORICAL REVIEW AND PATH ANALYSIS
}

\author{
Yang Li \\ Faculty of Education, Beijing Normal University (China)
}

\begin{abstract}
Based on the policy texts of private education since the founding of the People's Republic of China and from the perspective of historical institutionalism, this article draws the following conclusions: under the shaping of state policies in different periods, China's private education has experienced three main stages: the elimination of private education(1949 1978), the recovery and preliminary development of private education (1978 1992), and the rapid development of private education (1992 2016); the evolution of private education policy has experienced punctuated equilibrium and gradual transformation as two main modes, which is determined by critical junctures and path dependence; government power and market mechanism play the role of dynamic mechanism of institutional change. The article suggests that the state should further clarify the respective responsibilities of the government and the market mechanism to realize the positive interaction between them.
\end{abstract}

Keywords: Private education, education policies, historical institutionalism, government, market mechanism.

\section{Introduction: China's private education is now at a critical stage}

Private education is an important part of Chinese education. According to the 2017 national education development statistics bulletin published on the official website of the Ministry of Education of China, as of 2017, there were 177.6 thousand private schools at all levels, accounting for $34.57 \%$ of the total number of schools at all levels in the country; the number of students registered in private schools reached 51.2047 million, accounting for $19 \%$ of the total number of students in the country. (The Chinese Ministry of Education, 2018) Private education has made contributions in providing diversified and personalized education forms, improving the quality of education of the whole society, and safeguarding citizens' right to learn and receive education.

In 2016, China's legislature revised The Private Education Promotion Law, which was promulgated and implemented in 2002. According to the revised law, the state will continue to encourage private education, and the government shall create good conditions to promote the development of private education; in the meantime, the government should carry out classified supervision on different kinds of private schools, and private schools of the compulsory education stage are forbidden to operate for profit making. Besides, the government is about to make more detailed and strict regulations on the operation of private schools and educational institutions, such as running collectivization, merger and acquisition, being listed and so on. The strict management implemented by the state added to the worries of the whole society (especially the capital market) about the development prospect of private education, and it seems that private education in China is faced with challenges.

The expectation and anxiety of the private education industries to the new law is a miniature of the historical fact that development of private education was deeply influenced by the national policies since the founding of the People's Republic of China. The socialist nature of the state and public ownership economy occupying a leading position in economical operation have both led to the current situation that the public education dominates the whole education system in China. The survival and development of private education in China largely depends on the state policies, and it is the state that decides whether to tolerate its existence or encourage its development; at the same time, the market economy also has a profound impact on the development of private education. This paper will review the private education policies in various stages since the founding of the People's Republic of China, and explore the internal logic of the evolution of private education policies. 


\section{Analytical perspective: historical institutionalism}

Historical institutionalism is an important branch of New Institutionalism. Historical institutionalism developed in response to the group theories of politics and structural-functionalism prominent in political science during the 1960s and 1970s. (Hall \& Taylor, 1996) On the basis of absorbing and drawing lessons from the mainstream theories of structural-functionalism, conflict theory and New Marxism, the theory of historical institutionalism holds that the conflict of competing for scarce resources among different interest groups is the core of politics; the political and economic structure of society makes different interest groups occupy different positions in the conflict of interest with each other, and some groups' interests are satisfied while the others' are deprived. In this process, the state is regarded as not a neutral "intermediary" between competing interest groups but a complicated "institution" that can build group conflict. Historical institutionalism emphasizes the essence of the asymmetries of power in the process of institutional development, and the role of path dependence in the process of institutional continuation and change: under the established socio-political and economic structure, institutions give some people more power, and accordingly, those who obtain more power will further maintain the institution. Through the understanding of path dependence, historical institutionalists put forward the theory of institutional change. According to historical institutionalism, the process of institutional change is generally divided into the normal periods of institutional existence and the critical junctures of institutional fracture. In the normal period, institutional change follows the pattern of path dependence, and there is a certain balance between institution and social circumstances as well as within institution. However, in the period of institutional fracture, the fierce change of institution will be possible, (He, 2002) which is named "punctuated equilibrium" (Krasner, 1984) by some researchers. Historical institutionalism not only presents a suitable theoretical lens for understanding institutions and institutional change, but also offers an explanation for the sources of change. (Huang, 2017)

Historical institutionalism's theories on institution change provides a good perspective for us to analyze the evolution of private education policy since the founding of the people's Republic of China. The development process of private education presents several distinct stages, and the continuation of policies in each stage and the transformation of policies in different stages are subject to the existing political and economic structure of the state. The theory of historical institutionalism helps us to explore the essential power of determining institutional change.

\section{Historical review: the evolution of private education policy in China}

Through analyzing the policy texts and legal documents related to private education in different historical periods since the founding of the people's Republic of China, combined with different researchers' division of the development stages of private education in recent years, this article divides the development of private education into three main stages: the elimination of private education(1949 1978), the recovery and preliminary development of private education (1978 1992), and the rapid development of private education (1992 2016).

\subsection{The elimination of private education (1949 1978)}

During the period of the Republic of China (1912 1949), the national government allowed private schools to be set up, and there were various kinds of schools at all levels run by non-governmental organizations, citizen individuals and foreigners. In 1949, the People's Republic of China was founded, and the new government took over public schools run by old government at all levels in the country, and organized the reopening of schools; from 1950 to 1951, the state changed all the colleges and middle schools run by foreigners into public schools to "resume the exercise of educational sovereignty"; in 1952, the Ministry of Education carried out the adjustment of colleges and departments throughout the country, and changed all the private universities into public ones; finally, the Ministry of Education ordered all private primary and secondary schools in the country to be taken over by the government and changed to public schools. Since then, all kinds of schools at all levels had been transformed into socialist public schools, and public education became the only one legal form of education in China. Private education was declared no longer legal, banned, and eliminated.

During that period, the central government had also briefly introduced the policy of allowing the existence of private education, but the implementation effect of the policy is extremely limited. Private education could not survive because of its conflict with "pure socialist ideology". 


\subsection{The recovery and preliminary development of private education (1978 1992)}

Experienced ten years of social unrest during the Cultural Revolution from 1966 to 1976, the state began to reform its political and socio-economic system in 1978. On April 22, 1978, the Ministry of Education held a national education affairs conference in Beijing. Deng Xiaoping emphasized to improve the quality of education, improve the teaching level of science and culture, and better serve the socialist construction, which defined the basic direction for the development of education in the period. At the beginning of this stage, the state adopted an acquiescent attitude towards private education, which made private education began to recover slowly. According to statistics, from 1978 to 1982, eight private universities emerged in the field of higher education (Yang, 2002), and private primary and secondary schools and private vocational schools began to emerge. On December 4, 1982, the supreme legislature passed the Constitution of the People's Republic of China, which is known as the 1982 Constitution. It clearly stipulated that "the State encourages collective economic organizations, state enterprises and institutions and other non-governmental sectors to run various educational undertakings in accordance with the provisions of the law". From the perspective of the fundamental law of the state, it was clear that private education was allowed to run educational undertakings as "non-governmental sectors". On May 27, 1985, the Party passed The Decision of The CPC Central Committee on The Reform of Education System to encourage the development of private vocational education. On July 8, 1987, the former State Education Commission issued Several Interim Provisions on the Running of Schools by Non-governmental Sectors. It clearly stated that "running schools by non-governmental sectors is an integral part of China's education and a supplement to public schools", "governments at all levels and education administrative departments shall encourage and support non-governmental sectors to run various education undertakings, safeguard the legitimate rights and interests of schools, and protect the running of schools.", "try to help solve the difficulties in running schools, and commend and reward those who have made outstanding achievements in running schools." The state policy once again clarified the legitimacy of private education, and even encouraged private education to grow and expand. Private education seized this historical opportunity period and gradually grew in scale, and achieved its comprehensive recovery and preliminary development.

\subsection{The rapid development of private education (1992 2016)}

In 1992, the central government decided to establish a market economy system in an all-round way and abandon the original planned economy system, and therefore, education policy of the state should be altered to fit in the market economy. In 1993, the state issued The Outline of China's Education Reform and Development, pointing out the basic tasks of education reform under the requirements of establishing a "socialist market economy system". The outline points out that social organizations and individual citizens should be encouraged to run schools, and the government should encourage enthusiasm of the people in running schools and raise educational funds through various channels. Specifically, in order to raise funds for education and promote the development of education, the outline stipulated that the state encouraged and advocated factories, mining enterprises, institutions, social organizations and individuals to donate money to help students and raise funds for running schools, excluding taxes, and welcomed compatriots from Hong Kong, Macao and Taiwan, overseas Chinese, foreign groups and foreigners to provide financial support and donations to education. In order to raise funds for education, the state took the initiative to introduce private capital and foreign capital, and began to attach importance to the role of the market economy in the allocation of educational resources, which promoted the development of private education. In 1997, the State Council promulgated The Regulations on Running Schools by Non-governmental Sectors. The regulations not only clearly defined the rights, obligations and legal responsibilities of the schools run by non-governmental sectors, but also clearly defined the responsibilities of government to guarantee and support the running of schools by non-governmental sectors, which is a milestone in the development of private education.

In the 21 st century, private education ushered in greater historical opportunities. At the end of 2002, the supreme legislature promulgated The Private Education Promotion Law, which marked the establishment of the legal system of China's private education. Private education started on the right track of running schools and teaching students according to law. With the comprehensive protection of national policies and laws for the legitimate rights and interests, private education has started a rapid development for more than ten years. According to the statistics of the Ministry of Education, at the end of 2002, the number of private schools at all levels and types in China was 61200, with a total number of 11.1597 million students (The Chinese Ministry of Education, 2004); by the end of 2015, the number of private schools increased to 155200 , with a total number of 43.0191 million students (The Chinese Ministry of Education, 2015). Private education has grown into an important force that cannot be ignored by the state, government and society. 


\section{Path analysis: from a historical institutionalism perspective}

Based on the theories of historical institutionalism, this study believes that as a kind of institutional change, the evolution of private education policy has gone through punctuated equilibrium and gradual transformation as two main modes, which is determined by critical juncture and path dependence; government power and market mechanism plays the role of dynamic mechanism of institutional change.

\subsection{Punctuated equilibrium led by government power: 1949 1978}

Since the founding of People's Republic of China in 1949, the new proletarian regime controlled over all industries in the country in a very short period of time, and rebuilt the whole national machinery according to the socialist ideology. In order to maintain ruling stability, the government managed to take full control of education system and transformed it into one that obeys the orders of the proletariat. Private education was defined as "bureaucratic capitalism, imperialism and feudalism" and eliminated by the state. During this period, the evolution of private education policy showed the characteristics of punctuated equilibrium, and the establishment of new regime was the first "critical juncture" in the process of private education policy change: under the strong direct interference of government power, the original education system was completely ruined.

\subsection{Gradual transformation led by government power: 1978 1992}

The second critical juncture in the process of private education policy evolution is that the state began to reform its political and socio-economic system in 1978. However, the institution had formed strong inertia and path dependence, and it was difficult to change it rapidly in a short time. Therefore, from 1978 to 1992, the state adopted a gradual reform policy, gradually reforming the old system and introducing new systems. In the field of education, the state had gradually reduced various restrictions on private education. From the initial acquiescence to its existence, it had gradually developed into a positive norm to guide its development and actively protect its rights and interests. At this stage, the evolution of private education policy showed obvious characteristics of gradual transformation, and the leading force to promote the system transformation was the government power.

\subsection{Gradual transformation led by both government power and market mechanism: 1992 2016}

In 1992, the state proposed to establish a market economy system, which became the third critical juncture in the process of private education policy evolution. A series of policies and legal texts encouraging the development of private education played a role in promoting private capital investment and running schools. Private education has achieved the fullest development with the help of market mechanism. In the process of advancing education reform and promoting the development of private education, the government had gradually transferred part of its power to the market mechanism. With the establishment and improvement of market mechanism, the market had gradually mastered the initiative to promote the development of private education. Under the market economy, the first batch of empowered private education subject had become the group of vested interests. They held the right of discourse that cannot be ignored in the later process of private education policy making, which had a profound impact on the trend of policy. However, the rapid development of private education has also brought some negative effects, including the expansion of education gap and the rising of family expenditure on education.

\section{Conclusion: build positive interaction between government power and market mechanism}

The development of private education is deeply influenced by state policies, and government power as well as market mechanism affect private education directly. Looking back on the history, the absence of either government responsibility or market economy will have a negative impact on the development of private education, so the article suggests that the state should further clarify the respective responsibilities of the government and the market mechanism to realize the positive interaction between them. The government should not only encourage the development of private education, but also take necessary supervision to prevent it from excessive profit seeking and damaging the education equity. 


\section{References}

Hall, P. A., \& Taylor, R. C. R. (1996). Political science and the three new institutionalisms. Political Studies, 44(5), 936-957.

He, Junzhi. (2002). Structure, history and behavior: an analytical paradigm of historical institutionalism. Social Sciences Abroad, (05): 25-33.

Huang, C. (2007). The changing politics of UK central government under Europeanisation since the Maastricht treaty: A historical institutionalist analysis and its limitations. Retrieved from https://search.proquest.com/docview/898744229?accountid $=8554$

Krasner, S. (1984). Approaches to the State: Alternative Conceptions and Historical Dynamics. Comparative Politics, 16: 223-46.

Yang, Quanyin. (2002). Reflections on the policy of private education in China for 20 years. Heilongiiang Higher Education Research, (02): 18-21 